\title{
BOGATSTVO I TRAJNOST LJUDSKIH PRAVA U VRELIMA PRAVA (DOKUMENTIMA) MEĐUNARODNE ORGANIZACIJE RADA (100 GODINA MOR-A, 1919.-2019.)
}

Prof. dr. sc. Marinko Učur*

UDK.: $341.018: 349.2$

https://doi.org/10.30925/zpfsr.41.1.13

Ur.: 21. veljače 2020.

Pr.: 28. ožujka 2020.

Pregledni rad

Za glavara tvoga postavit ću Mir, Pravdu za vladara (Biblija, Iz 60, 17)

\section{Sažetak}

Osnivanjem i početkom rada Međunarodne organizacije rada 1919. godine nastavljen je višestoljetni put i razvoj prirodnih prava (ljudskih prava ,prava čovjeka") i njihovo pravno oblikovanje u hirovitim i heterogenim odnosima (svih sadržaja) u svijetu. Već je stotinu godina na snazi Ustav MOR-a na temelju kojeg je Opća skupština UN-a donosila konvencije i preporuke i druge dokumente o uvjetima rada ( $u$ najširem smislu riječi), koje su ratifikacijom i prihvaćanjem postale dio pravnoga sustava država $i$ po pravnoj snazi iznad nacionalnog zakona. Vrela prava UN-a i drugih legalnih $i$ legitimnih međunarodnih $i$ regionalnih organizacija, načela i norme prava koje je stvorio (i stvara) MOR, čine korpus međunarodnog radnog (i socijalnog) prava.

Predmet je ovoga rada osvrt na stogodišnje bogatstvo stvoreno pod okriljem MOR-a o ljudskim pravima i slobodama, ponajprije na radu (prava i slobode čovjeka na radu) $i$ stajalište da nijedna pravna norma pozitivnoga prava ne smije kolidirati s načelima i pravilima o ljudskim pravima i slobodama.

Ključne riječi: Međunarodna organizacija rada; ljudska prava i slobode; vrela međunarodnog radnog prava; uvjeti rada i prava čovjeka na radu.

\section{UVOD}

Ustav Međunarodne organizacije rada (MOR) (engl. International Labour Organization - ILO; franc. Organisation Internationale du Travail -OIT) i na temelju

* Dr. sc. Marinko Učur, redoviti profesor u trajnom zvanju, u mirovini, Sveučilište u Rijeci, Pravni fakultet; marinko.ucur051@gmail.com. 
njega donesene konvencije i preporuke univerzalna su, pisana vrela suvremenih (kolektivnih i individualnih) radnih odnosa. To su ,uz dokumente Ujedinjenih naroda (UN) i drugih legitimnih međunarodnih organizacija" te uz konvencije i povelje Europske unije (EU) i Vijeća Europe (VE), odnosno drugih regionalnih organizacija (na drugim kontinentima svijeta), najvažnija i najsveobuhvatnija vrela radnoga prava, odnosno temeljnih ljudskih prava i sloboda (prava čovjeka) kao prirodnih prava. ${ }^{1}$

„Redoslijed“ donošenja konvencija i preporuka MOR-a svojevrsno je kazivanje o razvoju te organizacije, ali i razvoju međunarodnoga radnog prava i želje da se ostvari cilj u brizi za životne i radne uvjete čovjeka na radu. U njima su određeni pojmovi, kategorije, instituti i radnopravni (dijelom i socijalnopravni) odnosi koji su omogućili stogodišnji i današnji razvoj tih složenih i specifičnih pravnih odnosa. Oni se stalno razvijaju, prvenstveno u pozitivnopravnim normama što ih donose ,nadležna“ tijela (organi) pojedinih država. Njih je teško, ali nužno pratiti. Pozitivnopravna „rješenja“ ne smiju kolidirati s načelima i pravilima o ljudskim pravima. „Zamjenu“ za ta opća ljudska prava ne treba (i ne može se) tražiti (naći). Potrebne su primjene i promjene, ali one moraju naći uporište u navedenim vrelima prava. Ratifikacijom Konvencije, ona postaje dio pravnoga sustava države (po monističkoj teoriji) bez donošenja zakona o odnosima koji su konvencijom uređeni, neposredno se primjenjuje i ,,po pravnoj snazi je iznad zakona".2

Bez obzira na brojna vrela (primarna i sekundarna u pravu, pravnoj stečevini EU-a (acquis communautaire) ne treba stvarati umjetnu koliziju i ,problem“ hijerarhije između tih vrela i konvencija MOR-a ako je riječ o ljudskim pravima (pravima čovjeka), kao prirodnim pravima u sadržaju radnopravnih (i socijalnopravnih) odnosa. Ljudske slobode ili prava jesu, postoje, ili nisu, odnosno ne postoje u praksi. No, taj odnos još treba ,,izučavati““.

Razvoj radnog prava (posebno međunarodnoga radnog prava) dosta „duguje“ osnivanju i radu MOR-a od 1919. kada je osnovan u Parizu (u Versaillesu, ugovorom o miru nakon završetka Prvog svjetskog rata). Od početka do danas ( $a$ in futuro) rad (stvaranje novih proizvoda i obavljanje usluga) je odrednica radnih odnosa, kao i uvjeti rada u svim ,relacijama“ (vremenu i prostoru), bez obzira na način njegovog organiziranja i realizaciji (individualno ili timski, zajednički), smišljeno, usklađeno i korisno. Rad za drugoga poseban je predmet uređivanja, ostvarivanja i zaštite. ${ }^{3}$

\section{OSNIVANJE, CILJEVI I KARAKTERISTIKE MOR-A}

MOR je utemeljen kada i Liga naroda 1919. godine, nakon milijunskih žrtava i nenadoknadive štete u Prvom svjetskom ratu. Najvažniji razlog koji je uvjetovao osnivanje te organizacije osiguravanje je boljih uvjeta rada i položaj radnika u cijelom

1 Marinko Učur i Sandra Laleta, Konvencije Međunarodne organizacije rada, s komentarima (Zagreb, Rijeka: TIM press, Pravni fakultet, 2007.); Slobodan Perović, Besede s Kopaonika (Beograd: Kopaonička škola prirodnog prava, 2011., 2012.) i dr.

2 Čl. 140. Ustava Republike Hrvatske Narodne novine, br. 56/90. do 5/14.

3 U pitanju je radni odnos bez obzira na trajanje, vrijeme i način obavljanja „operacija“ (poslova i zadataka). To je rad za drugoga i u službi drugoga; rad za plaću, po nalogu i uputama poslodavca i po pravilima struke. Vidi Marinko Učur, Vrela radnog prava (Rijeka: Pravni fakultet, 1996.). 
svijetu te osiguravanje pristojnog (prikladnog, odgovarajućeg) posla za sve. ${ }^{4}$

U Ugovoru o miru, kojeg su 28. lipnja 1919. potpisale u Versaillesu savezničke i pridružene sile, s jedne strane, i Njemačka, s druge strane, $\mathrm{u}$ „Dijelu XIII. članci 387. do 427.“ i u Preambuli, upisan je Ustav MOR-a. Međunarodna konferencija (skupština) rada na 25. zasjedanju održanom 10. svibnja 1944. u Philadelphiji, usvojila je „Filadèlfījsku deklaraciju“ koja je sastavni dio Ustava MOR-a. ${ }^{5}$ Tijekom Drugog svjetskog rata Liga naroda je, takoreći bila „,blokirana“, ali je MOR (,preseljenjem“ sjedišta iz Ženeve u Montreal) nastavio s radom. Tako je 1944. na Konferenciji MOR-a, kojoj su prisustvovali predstavnici 41 država članica, donesena Filadelfijska deklaracija u kojoj su (ponovno) definirani ciljevi i zadatci MOR-a u novonastalim uvjetima.

Glavni direktor Međunarodnog biroa rada, nakon toga je izjavio: ,... uređenje mira poslije ovoga rata odlučit će o čitavoj budućnosti civilizacije“. 6

U „Preambuli“ i odredbama Ustava upisana su polazišta za životne i radne uvjete ljudi i osiguravanje socijalne pravde:

- svjetski mir može biti zasnovan samo na temelju socijalne pravde;

- loši uvjeti rada donose velikomu broju osoba nepravdu, bijedu, siromaštvo, što ima za posljedicu nezadovoljstvo koje ugrožava svjetski mir;

- svaka država treba propisati (i usvojiti) takav humani (ljudski) „režim rada“, ne samo zbog pravde, zbog toga što je neusvajanje takvog režima rada zapreka i drugim državama koje žele poboljšati uvjete rada;

- postavljeni ciljevi MOR-a mogu se ostvariti, pored ostalog, propisivanjem broja radnih sati, određivanjem maksimalnog trajanja dnevnog i tjednog radnog vremena, borbom protiv nezaposlenosti, jamčiti „nadnice“ koje osiguravaju normalne uvjete egzistencije, zaštitom protiv općih ili profesionalnih bolesti i nesreća na poslu, zaštitom djece (mladeži) i žena, davanjem starosnih i invalidnih mirovina i drugih radnih (i socijalnih) prava.

Filadelfijska deklaracija, posebno ističe:

1. rad nije roba, odnosno radna snaga ne smije više biti roba koja se kupuje i prodaje;

2. bijeda, gdje god postoji, opasnost je za napredak;

3. borbu protiv bijede i neimaštine treba voditi u sklopu svake države i uz ravnopravnu suradnju radnika i poslodavaca s vladama;

4. sloboda izražavanja i udruživanja prijeko je potreban uvjet za stalni napredak;

5. zapošljavanje na takvim poslovima i zanimanjima na kojima radnici mogu

4 Učur, Vrela radnog prava, 115; Mehmed Kenović i Sead Dedić, Osnovi radnog prava, 2. izd. (Sarajevo: Pravni fakultet, Studentska štamparija Univerziteta, 1999.), 13; Željko Buklijaš, Kolektivno radno pravo (Split: Pravni fakultet, 2006.); Sead Dedić i Jasminka Gradašćević Sijerčić, Temelji međunarodnog radnog prava (Sarajevo: Pravni Centar FOD BIH, 2000.); Branko Lubarda, Evropsko radno pravo (Podgorica: CID, 2004.); Roger Blanpain, European Labour Law (London/New York: Walters Kluwer, 2003.).

5 Tekst Ustava MOR-a (u cjelovitom tekstu) objavljen je u Marinko Učur, Radnopravni status pomoraca (Rijeka: Pravni fakultet, 2003.), 173-188.

6 Vilim Herman i Milorad Ćupurdija. Osnove radnog prava, (Osijek: Pravni fakultet, 2011.), 34 35 i dalje. 
najviše iskazati svoje sposobnosti;

6. osiguravanje osposobljavanja radnika i drugih prava u vezi s navedenim i drugim pravima.

Poseban sporazum između MOR-a i UN-a zaključen je 19. prosinca 1946. Njime se precizirala: pravna osobnost MOR-a. MOR postaje specijalizirana organizacija UN-a, koja je, na temelju svoga Ustava, odgovorna za poduzimanje odgovarajućih mjera i ostvarivanje ciljeva predviđenih njime. Sporazumom se određuje pod kojim će uvjetima predstavnici UN-a prisustvovati sjednicama Opće skupštine (konferencije) MOR-a i osigurava da predstavnici MOR-a sudjeluju na zasjedanjima Generalne skupštine UN-a, njezinih komisija i Ekonomsko-socijalnog vijeća.

MOR kao organizacija razlikuje se od drugih međunarodnih organizacija po karakteristikama, a to su:

1. stalnost i neprekidnost (osnovna je radi kontinuiranoga proučavanja, reguliranja pa i zaštite prava i odnosa u području rada i socijalne politike (socijalne sigurnosti u širem smislu) i poduzimanje mjera radi rješavanja tih problema, odnosno poboljšavanja radnih i životnih uvjeta, realno govoreći, taj cilj u cijelosti ne može ostvariti niti MOR niti drugi legitimni i legalni subjekti);

2. univerzalnost (MOR je stvorena (osnovana) kako bi postao univerzalnom organizacijom koja nije ograničena samo na određene države (zemlje), već da bi se uspostavila suradnja (,veza“) među svim državama na svim kontinentima svijeta u cilju formiranja „svjetske politike rada“ $i$ socijalnog razvoja) te

3. tripartitnost (MOR je jedina međunarodna organizacija u kojoj su, i u svim njezinim tijelima, zastupljeni predstavnici vlada, poslodavaca i radnika (sindikata) država članica). ${ }^{7}$

\section{ORGANIZACIJSKA STRUKTURA MOR-A}

Organizacijska struktura MOR-a utvrđena je njegovim Ustavom. To su tri (glavna) organa (tijela): Opća konferencija (skupština MOR-a), Upravno vijeće (administrativni savjet) i Međunarodni ured (biro) rada.

\subsection{Opća konferencija}

Opća konferencija (Generalna skupština, Međunarodna skupština rada, engl. International Labour Conference) skupština je država članica, vrhovni (najviši) i zakonodavni organ MOR-a. Jedina je, po Ustavu MOR-a, ovlaštena donositi propise u području rada. Imenuje članove Upravnog vijeća. Saziva se jedanput godišnje, a po potrebi i češće. ${ }^{8}$ Posebno je propisan njezin sastav (struktura): svaka država ima u skupštini četiri predstavnika (delegacija): dva zastupnika vlade, jednog predstavnika poslodavaca i jednog predstavnika radnika (sindikata), po reprezentativnosti poslodavaca i sindikata. Svaki član, ,delegacije“ ima pravo glasa (i u tome je samostalan i glasa po „svojoj volji“ i ,izboru“). Odluke donosi dvije trećine predstavnika većinom

7 Republika Hrvatska postala je članica MOR-a 6. kolovoza 1992.

8 Prvo zasjedanje Opće skupštine MOR-a održano je u Washingtonu 1919. U pravilu se održava u Ženevi. 
prisutnih. To je mjesto odlučivanja predstavnika vlade, poslodavaca i sindikata (socijalnih partnera) i jedinstveno je u svjetskim (međunarodnim) odnosima, po: normativnoj aktivnosti (donošenje konvencija, preporuka, rezolucija, izmjena Ustava MOR-a); izboru članova tijela (organa) MOR-a, izvješćima i drugim utvrđenim pitanjima. ${ }^{9}$

\subsection{Upravno vijeće}

Upravno vijeće (engl. Governing body) u svojstvu izvršnog organa znatno utječe na Opću skupštinu (konferenciju) i Međunarodni ured rada (brzina provedbe odluka Skupštine i neprekidni nadzor nad radom Ureda). Sastaje se tri puta godišnje. Po Ustavu MOR-a ima 56 članova, koje na mandat od tri godine biraju skupine vladinih, radničkih i poslodavačkih delegata (predstavnika) na Općoj skupštini (konferenciji), a čine ih stalni članovi određenih predstavnika vlada najrazvijenijih zemalja (10) i 18 ,nestalnih“ članova (ukupno 28) te po 14 predstavnika poslodavaca, odnosno 14 predstavnika radnika. Najvažniji su poslovi: priprema rada konferencije (i regionalnih konferencija), priprema programa rada i proračuna te opći nadzor nad poslovima MOR-a).

\subsection{Međunarodni ured rada}

Međunarodni ured rada (engl. International Labour Office) stalno je tajništvo (sekretarijat), posebno tijelo na čijem čelu je generalni direktor MOR-a. Glavna mu je uloga „veza“ i koordinacija s vladama, poslodavcima i radnicima (sindikatima) država članica. Stručnim, znanstvenim i drugim radom (uz pomoć preko 300 radnika) priprema sve „materijale“, a pogotovo međunarodne instrumente (konvencije i preporuke) za konferencije, regionalne konferencije, upravno vijeće i dr.; pruža pomoć državama; vodi izdavačku i izvještajnu djelatnost; prati primjene konvencija i drugih dokumenata MOR-a i dr. Stručni se rad obavlja u odjelima (opće, stručne i tehničke službe).

\subsection{Generalni direktor}

Generalni direktor (engl. Director-General) nalazi se na čelu Međunarodnog ureda rada. Bira ga Upravno vijeće na petogodišnji mandat i njemu odgovara za djelotvoran rad ureda. Prima izvješća od država članica, priprema izvješća o konvencijama i drugim dokumentima, bira i postavlja osobe (radnike) Ureda, obavlja i druge poslove utvrđene aktima Upravnog vijeća.

\subsection{Regionalne konferencije}

Regionalne konferencije MOR-a su „veza“" s pojedinim dijelovima svijeta, za pružanje pomoći vladama, poslodavcima i radnicima (sindikatima) radi približavanja

9 Deklaracija o osnovnim načelima i pravima na radu iz 1989. (engl. ILO Declaration on Fundamental Principles and Rights at Work) utvrđuje nadležnost skupštine da provjerava izvješća koja se tiču „četiriju osnovnih prava“ (Global Report). 
nacionalne i regionalne realnosti. To je oblik „razmjene mišljenja i iskustva“ država određenih regija radi specifičnih socijalno-ekonomskih pitanja i otklanjanje neravnomjernosti. Strukturu (sastav) regionalne konferencije odgovara strukturi opće skupštine (2+1+1 iz svake „regionalne“ države). Ne mogu donositi konvencije i preporuke, ali donose odluke o bitnim pitanjima u formi rezolucija (stručno obrazovanje, politika plaća, socijalno osiguranje, profesionalni odnosi, uvjeti rada, radni i socijalni problemi u različitim granama gospodarstva i drugim problemima) koji zahtijevaju „razmatranje u širim međunarodnim uvjetima“..$^{10}$

\subsection{Komisije i odbori}

Komisije i odbori (komiteti) u sastavu MOR-a osnovani su za pojedine sektore, djelatnosti, pitanja i odnose (probleme) kojima se bavi MOR. Mogu biti stalni i povremeni. Okupljaju, uglavnom stručnjake određenog područja, a to su: Odbor za slobodu udruživanja; Odbor za programe, financije i administraciju; Odbor za pravna pitanja i međunarodne radne standarde; Odbor za zapošljavanje i socijalnu politiku; Odbor za sektorske i tehničke sastanke is time povezana pitanja te Odbor za tehničku suradnju.

Svako od navedenih tijela ima propisane ovlasti, program rada, način rada i odlučivanja (poslovnik i drugo).

\section{NORMATIVNA AKTIVNOST MOR-A}

MOR ima nezamjenjivu ulogu i važnost u stvaranju normi, standarda i osnova međunarodnoga radnog prava. Na temelju i u skladu s Ustavom, donesene su brojne konvencije i preporuke, programi, smjernice i drugi akti. Jedni imaju, a drugi nemaju „obveznu“ snagu, razlikuju se po postupku donošenja, upućivanju državama članicama, praćenju prihvaćanja, primjene i dr.

\subsection{Konvencije i preporuke MOR-a}

Najvažniji, najčešći i posebno karakteristični propisi MOR-a, pored Ustava su konvencije. To su propisi međunarodnog karaktera s posebnim nomotehničkim objektivnim oznakama (značajkama). To su: nadležnost donošenja; preambula (uvodna odredba), naziv (ime) koji se sastoji od ,imena (vrste) propisa, broja, naziva (koji konvenciju razlikuje od drugih konvencija), sadržaj, postupak, prostorno i vremensko važenje (stupanje na snagu, obveznost, otkazivanje i otkazni rokovi, revizija, potpisivanje i ,pohranjivanje). Pored toga, bitno je istaknuti i subjektivne nomotehničke pretpostavke (znanje, jezik, timski rad i dr.).

Konvencijama MOR-a definiraju se (utvrđuju se) norme međunarodnoga radnog zakonodavstva. Donošenjem (izglasavanjem) konvencije na Općoj skupštini

10 Postoje programi i konferencije za područja: Afrike, Latinske Amerike i Kariba, arapskih država, država Azije i Pacifika, Europe i Središnje Azije. Hrvatska je dio subregionalnog ureda za srednju i istočnu Europu, osnovanog 1993., sa sjedištem u Budimpešti (i pokriva 17 država), koji uključuje brojne aktivnosti. 
(konferenciji) MOR-a ona ne stupa na snagu, a primjenjuje se samo u onoj državi koja je ratificirala određenu konvenciju. Donesena je kako bi se primjenjivala u državama članicama, pa se može govoriti o adresatima u širem smislu (država koja konvenciju ratificira) i adresatima u užem smislu (subjekti na koje se primjenjuje sadržaj konvencije).

Preporuka se ne ratificira. Kada je država prihvati predstavlja odgovarajuće smjernice za državnu politiku i uređivanje radnih odnosa i ima ,savjetodavni karakter“.

Konvencijama i preporukama MOR postavlja minimalne standarde ljudskih prava u radnim odnosima.

\subsubsection{Obveza države članice u vezi s usvojenom konvencijom}

Nakon donošenja konvencije generalni direktor konvenciju dostavlja svim državama članicama na ratifikaciju, bez obzira na to jesu li tu konvenciju glasale na skupštini pri donošenju. Zakonodavstvo države propisuje postupak ratifikacije, odnosno postupanje s konvencijom nakon dostavljanja. Pri ratifikaciji sadržaj konvencije, u pravilu se usvaja u cijelosti, osim ako je u samoj konvenciji upisana „mogućnost“ (izrijekom dopušteno) „stavljanje rezervi“.

Država članica obavještava generalnog direktora Međunarodnog biroa rada „o poduzetim mjerama“ ili o ratifikaciji konvencije, ili se ne dobije „suglasnost“ zakonodavnoga tijela države za ratifikaciju. U ovom (drugom) slučaju obveza je države, u određenim rokovima, podnositi izvještaj „o stanju mjerodavnog zakonodavstva i prakse u pogledu pitanja koje je predmet konvencije“, razloge takvog postupanja i način kako će se to „urediti“.

Prema čl. 19. st. 8. Ustava MOR-a: „Ne treba ni u kom slučaju smatrati da usvajanje jedne konvencije ili preporuke, od strane konferencije ili ratifikacije konvencije od strane jednog člana utječu na bilo koji zakon, presudu ili sporazum koji osigurava povoljnije uvjete zainteresiranim radnicima od onih koji su predviđeni konvencijom ili preporukom“.

Država članica koja ratificira konvenciju dostavlja Međunarodnom uredu (birou) rada izvještaj (godišnje) o pripremi konvencije, ,u formi koju odredi Upravno vijeće“ i s određenim podatcima. Vlada države takav izvještaj dostavlja i reprezentativnim organizacijama poslodavca i sindikata. Na „prigovor“ tih organizacija vlada države dužna je „očitovati se“ Međunarodnom uredu rada. Država može ulagati prigovor i „tužbe“ protiv druge države, a postupak propisuju odredbe članka 26.-34. Ustava MOR-a.

Konvencija se može otkazati po proteku deset godina, uz otkazni rok od godinu dana. Ako se propusti taj rok „novi“ rok je ponovno deset godina primjene.

\subsubsection{Sadržaj konvencija}

Ustav MOR-a određuje sadržaj konvencija. Moglo bi se reći, da nema ni jednoga pitanja koje se odnosi na radne odnose i uvjete rada o kojima se nije odlučivalo na Općoj skupštini (konferenciji) MOR-a, a brojna su uređena konvencijama i preporukama. Taj se proces nastavlja i mora „pratiti“ razvoj gospodarstva, novih 
tehnologija, suvremenu organizaciju rada i druge djelatnosti i odnose.

Konvencija je međunarodni ugovor „usvojena u krilu MOR-a kao međunarodne organizacije“. To je mnogostrani međunarodni ugovor. MOR je međunarodni pravni subjekt. Konvencija je, po pravnoj snazi, iznad zakona. Mora se objaviti (jer je to obveza kada se provede postupak ratifikacije). Konvencija se ratificira (prihvaćanjem, odobrenjem, potpisivanjem, notificiranjem), a ne pristupanjem. Država time daje svoj „pristanak“ biti „vezana“ međunarodnim ugovorom (konvencijom). To utvrđuju ustavi država (,zakoni nad zakonima“).

Međunarodni ured (biro) rada, na temelju dokumenata Upravnog vijeća MOR-a, posebno traži od država „izvješća“ (engl. Global report) o konvencijama (i u praksi) uređena i ostvarena o četiri „temeljna prava“: na udruživanje te priznanja prava na kolektivno pregovaranje; uklanjanje svih oblika prisilnog rada; ukidanje različitih oblika dječjeg rada te ukidanje različitih oblika diskriminacije na poslu.

Konvencije (i preporuke) rezultat su dugotrajnoga postupka (statističkih i drugih podataka, izvješća i analiza, stanja u pojedinim državama i u svijetu) timskog rada, stručnjaka u odborima i drugih, koji je u pravnom smislu „neprekidan i usklađen međunarodnim naporom"." ${ }^{11}$

Predstavnici radnika i poslodavaca, surađujući „ravnopravno s predstavnicima vlada, sudjeluju u slobodnom raspravljanju i demokratski u odlučivanju, a na unaprjeđenju zajedničkog dobra“. To, onda čini sadržaj konvencija, ostvarujući načela i zadatke MOR-a. „Svako ljudsko biće (neovisno o rasi, vjerovanju ili spolu) ima pravo ostvariti (postizati) svoj materijalni napredak i duhovni razvoj u slobodi i dostojanstvu, u ekonomskoj sigurnosti i s jednakim izgledima“. ${ }^{12}$ To su prava čovjeka (ljudska prava, prirodna prava). Uz to, ,središnji cilj svake nacionalne i internacionalne politike“ treba biti „ostvarivanje uvjeta koji će omogućiti postizanja (navedenih) takvih rezultata, a programi i mjere u svim djelatnostima „moraju biti ocjenjeni s tog gledišta“. To MOR uključuje ,u svoje odluke i preporuke... ako ocjeni da su za te svrhe podnesene“" ${ }^{13}$

MOR pomaže „različitim zemljama svijeta“: za „postizanje pune zaposlenosti i višeg životnog standarda“; da radnik pokaže „svoje sposobnosti“; omogućavajući mu obrazovanje; kretanje radne snage plaće i zarade; trajanje radnog vremena; poboljšanje radnih uvjeta; poboljšanje organizacijske proizvodnje; mjere socijalne politike, odnosno socijalne sigurnosti (punu zdravstvenu zaštitu, odgovarajuću zaštitu života i zdravlja radnika svih zanimanja, zaštitu majke i djeteta); ,jednaki izgledi obrazovanja i profesionalnog života". ${ }^{14}$

Ti i toliki zahtjevi mogu se ostvariti (više ili manje) uz: unapređenje proizvodnje i potrošnje u međunarodnim i nacionalnim okvirima, sprječavanje „težih fluktuacija“ u gospodarstvu, ekonomski i socijalni razvoj, veću stabilnost cijena, sirovina, živežnih potrepština, naprednu svjetsku trgovinu, uz suradnju svih legalnih i legitimnih međunarodnih i nacionalnih subjekata, uzimajući u obzir „stupanj socijalnog i

11 Nikola Tintić, Radno i socijalno pravo. Knj. 1.: Radni odnosi (Zagreb: Narodne novine, 1969.), 180.

12 Tintić, Radno i socijalno pravo, 180.

13 Ustav MOR-a, (Filadelfijska deklaracija..., 10. svibnja 1944.), glava II.

14 Ustav MOR-a, glava III. 
ekonomskog razvoja“ u pojedinim državama i u svijetu.

MOR mora pratiti tehnički i tehnološki napredak u svijetu i nastaviti s normativnom, ali i drugom aktivnošću (istraživačka i informativna djelatnost, djelatnost u ekonomskim i socijalnim kretanjima i odnosima i dr.).

Konvencije MOR-a „stvaraju minimume“ u radnome pravu, kako bi bili primjereni svim državama članicama, da bi one svojim nacionalnim zakonodavstvom, prema svojim specifičnim mogućnostima, osigurale viši stupanj uvjeta rada (prava) koja uređuje konvencija. To se posebno odnosi na nezaposlenost i zapošljavanje; opće i posebne uvjete rada, rad djece, zaštitu žena radnica; zaštitu zdravlja i sigurnost na radu (pravo osobne zaštite na radu); sindikalne slobode; kolektivno pregovaranje; migracije radne snage; zabranu prisilnog rada i diskriminacije (po bilo kojoj osnovi); specifične radne odnose (npr. pomorci, u poljoprivredi i dr.) socijalnu sigurnost; plaće i materijalna prava, stalnost radnog odnosa i dr.). To se ostvaruje u stalnom sukobu interesa rada i kapitala; sukobu stavova i koncepcija, ali uz veću stabilnost i ostvarivanje konvencijama utvrđenih prava. ${ }^{15}$

Ponovimo, konvencijama su „formulirani“ međunarodni radni standardi o osnovnim ljudskim pravima, koji obuhvaćaju „cjelokupni spektar problema vezanim uz rad".

\section{SNAGA VRELA PRAVA MOR-A}

Od osnivanja MOR-a vrela prava koje je ta organizacija donijela i pratila njihovo ostvarivanje i zaštitu, potvrđuju opravdanost i snagu njenog postojanja i tih vrela. Sadržaj donesenih konvencija (i preporuka) potvrđuje tu opravdanost i snagu, stabilnost i održivost u složenim radnim (socijalnim i drugim) odnosima u svijetu i u pojedinim državama svijeta. Ono čine temeljnu značajku prava čovjeka na radu (i u vezi s radom), odnosno ljudskih prava, kao prirodnih prava. Istina je da pozitivno pravo države nije dostiglo zahtjeve tih prava. Razlog je što se to pozitivno pravo uređuje voljom vlasti (zakonodavca) u određenoj državi, koje određuju brojni uvjeti i okolnosti u kojima se donose propisi. Međutim, pozitivno pravo mora se „upravljati, dopunjavati ili korigirati“" prema univerzalnom prirodnom pravu. ${ }^{16}$

Standardi prava čovjeka na radu, utvrđene u Ustavu MOR-a (a kasnije i u drugim vrelima) su univerzalni, pravedni i stalni (nisu prostorno ograničeni). Njih treba pratiti i na njima se treba graditi kultura, moral, pravna, socijalna, ekonomska, politička i druga stanja i kretanja, a ne obratno. ${ }^{17}$ Oni služe pravdi i „pravednom pravu“.

Smisao prava ne smije se tražiti u ,interpretaciji zakonskih paragrafa“. To važi i za radna prava. Pozitivno je pravo prolazno (npr. zakoni o radu u pojedinim državama „traju“, „na snazi“" su tri do pet godina). Zakonska rješenja treba tražiti (i pronalaziti) u vrelima ljudskih prava i sloboda. Nacionalna rješenja trebaju biti u skladu s međunarodnim standardima o ljudskim pravima, u njihovom integritetu. Nema ljudskih prava „nižeg i višeg ranga“. Sva su utemeljena na pravu na život i

15 Tintić, Radno i socijalno pravo, 206-208 i dalje.

16 Perović, Besede s Kopaonika, 7 i dalje.

17 Ljudska prava (engl. human rights), prava čovjeka (franc. droits de l'homme). 
pravu na slobodu. Pojmovi ,pravna država“ i „vladavina prava“ osiguravaju da se ljudska prava ostvaruju i zaštićuju. Zakoni, često „kolidiraju“s rješenjima u ustavima država. U tom je smislu pravilnije govoriti o izrazu ,ustavna država“, jer ustavi (,zakon nad zakonima“) načelno imaju norme o ljudskim pravima i slobodama. ${ }^{18}$

Kako se to, onda odnosi na rad i radne odnose? Pravo na rad pripada svakom čovjeku, a vlasnička struktura i opća kultura „određuju dimenzije i kvalitetu ovog prava“. ${ }^{19}$ Čovjek mora uživati plodove svoga rada. Uvjete za to dužni su stvarati svi legalni i legitimni subjekti. Međunarodna vrela su to proklamirala: Opća deklaracija o pravima čovjeka (1948.), Međunarodni pakt o ekonomskim, socijalnim i kulturnim pravima (1966.), Europska socijalna povelja (1966.), ali i Ustav, konvencije (i preporuke) MOR-a, drugi propisi i relevantni dokumenti.

Obveza je država da to implementiraju u svoj pravni sustav i da izričito navedu (,ponove“): svatko ima pravo na rad, slobodu izbora zaposlenja, na pravične i zadovoljavajuće uvjete rada i na zaštitu od nezaposlenosti; svatko, bez ikakve razlike ima pravo na jednaku plaću za jednaki rad (i naknadu) koja njemu i njegovoj obitelji osigurava egzistenciju koja odgovara ljudskom dostojanstvu; pravo na sigurne i zdrave uvjete rada; pravo na organiziranje i kolektivno pregovaranje; pravo djece, mladeži i žena; pravo na stručno obrazovanje; pravo na zdravstvenu zaštitu, pravo na dostojanstvo na poslu i druga.

Navedena prirodna prava ne mogu se revidirati, već se primjenjuju (i dopunjuju novim sadržajima) sukladno s vremenom i razvojem tehnologije i uvjeta rada, sukladno s tim pravima utvrđenim u vrelima ljudskih prava i sloboda. Može i treba postići više bez obzira na to kojim legalnim aktom to bilo utvrđeno, ,stavljajući čovjeka u središte“. Ta se prava moraju štititi ,u svjetlu društvenih promjena, socijalnog napretka kao i znanstvenog i tehnološkog razvoja“, a ,uživanje tih prava nameće odgovornosti i obveze poštovanja drugih osoba, zajednice ljudi i budućih generacija“" ${ }^{20}$

Države članice Vijeća Europe, kada su 1949 odlučile osnovati Vijeće Europe (engl. Council of Europe), u Preambulu Europske socijalne povelje, upisale su kao cilj, pored ostalog ,održanje i razvitak ljudskih prava i temeljnih sloboda“. U sadržaju propisuju 19 ,prava i načela“ (pravo na rad, pravo na primjerene radne uvjete, pravo na sigurnost i zaštitu zdravlja na radu, pravo na pravičnu plaću, pravo na organiziranje i pregovaranje $\mathrm{i}$ dr.). ${ }^{21}$

Dalekovidnošću članova Komisije za međunarodno radno zakonodavstvo, koja je izradila Povelju o radu i predložila uspostavljanje MOR-a, što je upisano u Versailleski mirovni ugovor, prvi je put u povijesti osnovana organizacija u kojoj predstavnici radnika (sindikata) imaju pravo glasovanja, kao i predstavnici poslodavaca i vlada (država). Načelo je tripartitnosti kamen temeljac za osnivanje i izgradnju MOR-a. Kao

18 Perović, Besede s Kopaonika, 34-35. „...sudbina prava (se)... odlučuje... u narodno-pravnom životu, u društvenom biću kao materijalnom izvoru prava..., a njegov legitimitet... stječe se društvenim titulusom koji nastaje putem demokratskog postupka izjašnjavanja“.

19 Perović, Besede s Kopaonika, 396.

20 Povelja temeljnih prava Europske unije (Preambula) u knjizi Nada Bodiroga-Vukobrat i Sanja Barić. Povelja temeljnih prava EU, s komentarom (Organizator: Zagreb, 2002.), 31 i dalje.

21 Europska socijalna povelja (engl. European Social Charter), Narodne novine - Međunarodni ugovori, br. 15/02., 8/03. 
i danas, započelo se s članicama ,različitog stupnja industrijskog razvoja (u to doba čak i kolonija) i „specifičnim uvjetima“ određene zemlje: zemlje u razvoju, razvijene i druge. Od kolonijalnog ropstva, „dovođenja radnika pod ugovorima“, povećanja broja kolonijalne radne snage, raznih oblika prisilnoga rada, od nepostojanja radnoga zakonodavstva, a tamo i gdje je postojalo kršilo se (nije poštovano), preko prvih konvencija o posebnim radnim i životnim uvjetima (migracijskih uvjeta, zdravstvenih uvjeta, rada djece i žena i dr.), ,pružanja tehničke pomoći, pomoći i ublažavanju problema nezaposlenosti i gospodarskog nazadovanja, pa posebnih problema u ratu i poslijeratnom razdoblju, donose se dokumenti o jamčenju sloboda, dostojanstva, sigurnih i jednakih mogućnosti bez obzira na rasnu i vjersku pripadnost i spol a „,siromaštvo je, bilo gdje opasnost za napredak svugdje“, do specijalizirane, jedine takve na svijetu, organizacije koja danas djeluje s predstavnicima radnika, poslodavaca i vlada 187 država članica MOR-a. Pored Ustava MOR-a, doneseno je 189 konvencija te 205 preporuka, što čini nezamjenjivi fond, svojevrsni kodeks međunarodnoga radnog prava. ${ }^{22}$

Nakon Drugog svjetskog rata trebalo je nastaviti i povećati aktivnosti MOR-a na zaštiti temeljnih ljudskih prava, unaprjeđenju životnih i radnih uvjeta i omogućavanju pune zaposlenosti, ali i pitanjima novih tehnologija, gospodarskim i društvenim promjenama (međunarodnim korporacijama, radnom okolinom i dr.). Tako, sve više, uz normativnu djelatnost, MOR pomaže u izradi radnih programa i programa obrazovanja (svjetski program za zapošljavanje i dr.).

Tripartitnost se učvrstila kao načelo u predstavljanju države članice u Općoj skupštini, ali svaki predstavnik ima jedan glas, ali glasuje kao pojedinac, bez obzira na to kako glasuju ostali predstavnici (,delegacija“ države: predstavnici vlade, poslodavaca i radnika). To se „proširilo“ i na različite oblike kolektivnoga rada (komiteti, upravno vijeće i dr.) pa su odluke tih tijela stajališta vlada, poslodavaca i radnika. Tripartitnost omogućava poslodavcima i radnicima (sindikatima) izravno sudjelovanje i utjecaj u međunarodnim poslovima (društvenim, gospodarskim, kulturnim, političkim i drugim) što izravno ili neizravno utječe na međunarodne radnopravne odnose. To se odnosi i na obrazovanje radnika i na tehničku suradnju što ima posebno važnost za radnike, rad na radnim mjestima, u vođenju poslova i ponašanje u radnoj okolini. Obrazovanje omogućava različite aktivnosti u podizanju životnog i radnog standarda. Tehnička suradnja MOR-a i država članica odnosi se na projekte o radnoj snazi, životnom standardu, unaprjeđivanju zapošljavanja, zdravstvenoj zaštiti i drugom.

Nezaobilazan je značaj statistike socijalne politike država (plaće, nesreće na radu, profesionalne bolesti, radni sati, životni troškovi, sloboda udruživanja, rad u javnim službama i dr.). ${ }^{23}$

Uvažavajući brojne činjenice (razloge i odnose), na temeljima vrela ljudskih prava stvaralo se pozitivno radno zakonodavstvo, prolazno, više ili manje podnošljivo. Propisi su trebali osigurati ostvarivanje i zaštitu radnih prava, ali su često ostajali kao „lijepe želje“ u krizama različitoga sadržaja, vremena i prostora. Ljudska prava i dalje

22 ILO - službena stranica, dostupno na: https://www.ilo.org/global/lang--en/index.htm

23 Međunarodni institut za proučavanje rada (engl. International Institute for Labour Studies); Godišnjak MOR-a (engl. Yearbook of Labour Statistics). 
ostaju kao pokretačka snaga „inspiracija i motiv“ uređivanja odnosa života i rada, puno kompromisa i tolerantnosti, $u$ humano organiziranom društvu i društvenosti i dostojanstvu čovjeka u različitim oblicima organiziranja među više od 6 milijardi ljudi u svijetu. Ljudska prava treba da „,izvedu svijet iz krize u kojoj se nalazi“.

„Standard“ tolerancije pod okriljem MOR-a put je i način ostvarivanja ciljeva te organizacije: predstavnici država se međusobno poštuju i uvažavaju različita mišljenja vlada, poslodavaca i radnika (sindikata) u demokratskoj ravnopravnosti. ${ }^{24}$

\section{DRUGA VRELA - DIO „KOMPOZICIJE“ LJUDSKIH PRAVA I SLOBODA}

Sloboda je nedjeljiva, nije određena za jednu skupinu ljudi. Sloboda ili postoji ili ne postoji. Sloboda ne trpi ekstremiste i ekstremitete. U svijetu rade i organiziraju se subjekti različitoga političkog određenja i tradicija. Ono što ujedinjava progresivni svijet jesu načela MOR-a i drugih općih i regionalnih vrela u kompoziciji ljudskih prava i sloboda. ${ }^{25}$

Ta su vrela dovela do prosperiteta u ostvarivanju ljudskih prava i sloboda do danas. To su univerzalna prava, međusobno povezana i uvjetovana. Odnose se na svakoga čovjeka u svijetu. Prate ih dobra praksa i ustaljeni mehanizmi, ali i njihova kršenja i nepoštovanja, različitih ideoloških i drugih ,podloga“. Ugrožavaju ih gospodarska situacija, nezaposlenost, strukturalne promjene, nesigurnost i ratovi, obeshrabrivanje zaposlenih i nezaposlenih, osjetljivih skupina (kategorija) i drugi razlozi. Ističe se neoliberalizam (sloboda tržišta, fleksibilizacija rada, deregulacija, smanjivanje socijalne zaštite, globalizacija itd). Podcjenjuje se udruživanje (pogotovo sindikata) i time slabljenje organizacija (udruga) jer pojedinac može biti jak samo kroz kolektivnu podršku, zaštititi svoja prava i slobode i unaprijediti životni standard (standard života i rada). To se odnosi i na legalne industrijske akcije.

Zakoni su beskorisni ako nisu osigurani mehanizmi za njihovu provedbu (realizaciju, ostvarivanje). To se posebno odnosi na radnička prava koja se moraju razvijati i širiti kao koncentrični krugovi iz svake ćelije radnog organiziranja, preko država i njihovih demokratskih organizacija (UN-a, MOR-a, Svjetske zdravstvene organizacije, EU-a i dr.). To sve dio sveopćeg mira koji mora biti pravedan, koji kažnjava agresore (bez obzira na povod i „razlog“). Norme akata o ljudskim pravima i slobodama, u pravilu, izražavaju standarde koji se moraju primjenjivati kao opće prihvatljive uz, da donose svekolika poboljšavanja u praksi, jer broj normi „ne predstavlja ocjenu vrijednosti““. ${ }^{26}$

\subsection{Vrela UN-a o ljudskim pravima i slobodama}

Usprkos brojnim potresima i opasnostima organizacija Ujedinjenih naroda

24 „Tolerantan znači biti pomirljiv, miroljubiv, trpeljiv, snošljiv, popustljiv, neagresivan, istinoljubiv, jednom rječju, tolerantan znači biti obziran.“. Perović, Besede s Kopaonika, 441.

25 Predrag, Brazzoduro, Sindikat pomoraca Hrvatske, Sindikalne slobode, Sindikalna akcija (Zagreb: 1996.), 33.

26 Brazzoduro, Sindikat pomoraca Hrvatske, 41. 
održala se kao (do sada) najveća i najuniverzalnija međunarodna organizacija. U području i odnosima uvjeta rada i radnih odnosa „prati“ je MOR, kao njezina specijalizirana organizacija.

Opća skupština UN-a donijela je brojne rezolucije, a Vijeće sigurnosti preporuke, koje, nažalost, često ignoriraju same članice te organizacije.

To je bila „sudbina“ i Lige naroda (1920.-1939.-1946.), bez obzira na razliku u ,prilikama“ u kojima je postojala. To se, ponajprije odnosi na pitanje rata (ratova), za koje neki kažu da su ,imanentni, trajni, neuništivi sadržaj povijesti ljudskog društva“. Srećom, prevladava mišljenje da „novi svjetski rat više ne bi riješio bilo čije probleme“ i ovo mišljenje „obilježava doba OUN“. Brojne probleme sigurno ne može riješiti ,uporaba sile“. Samo mir može osigurati razvoj država (ljudskih zajednica) i u njima čovjeka i njegovih zajednica. Umjesto vojne snage, UN i MOR imaju snagu u načelima na kojima su osnovane i ciljeva zbog kojih su utemeljene i zbog kojih postoje. To je najvažnije i u budućem razvoju svijeta i ovih organizacija u njemu, jer mirnim putem treba stvarati humanije i bolje uvjete života i rada ljudi. Razvojni procesi nisu i ne mogu biti zaustavljeni. UN i MOR imaju norme međunarodnoga karaktera utemeljene u Povelji UN-a (koja predstavlja „ustav“ UN-a) i u Ustavu MOR-a (1919. i 1944.). One su stvorene voljom država članica i one su odgovorne za budućnost tih organizacija.

Države članice su prisutne u UN-u, bile velike ili male, jake ili slabe, bile u sporu i suprotnim interesima i lošim međusobnim odnosima i pred „licem“ su ne samo država članica nego i pred cijelim svijetom. ${ }^{27}$

To su velike organizacije, s velikim nadležnostima, dužnostima i pravima, sa tijelima (organima) specifično organiziranim i s uređenim nadležnostima i strukturom. To za UN određuje Povelja UN-a (1945.), a za MOR Ustav (1919. i 1944.), koji su mnogostruki međunarodni ugovori. Povelja određuje UN kao najvažniju i univerzalnu međudržavnu organizaciju na svijetu. MOR je specifična univerzalna organizacija temeljenu na načelima tripartizma vlada, poslodavca i sindikata u državama članicama iz cijelog svijeta.

Iz prava na život i slobodu proizlaze i druga ljudska prava.

Liga naroda (nastala nakon završetka Prvog svjetskog rata) i UN (nastao nakon završetka Drugog svjetskog rata) osnovane su nakon stoljetnih nastojanja velikih mislilaca (filozofa) i državnika i njihovih planova, kao svjetske organizacije koje trebaju osigurati trajni mir, dostatno čvrste, uređene i s većim ovlastima i „zaista univerzalne“ (širi i stalni sustav opće sigurnosti i „napuštanje sile“), „osnovane na načelima suverene jednakosti svih miroljubivih naroda“.

$\mathrm{Za}$ radnopravne i socijalnopravne odnose posebno je važno osnivanje Gospodarskog i socijalnog vijeća UN i uređivanje odnosa MOR-a (i drugih) (kao specijaliziranih ustanova UN-a). Pojedine države članice UN-a često sprječavaju ispunjavanje zadataka $\mathrm{UN}-\mathrm{a}$ (npr. narušavanjem mira $\mathrm{i}$ sl.). No, navedene su organizacije vršile „snažan i pozitivan utjecaj na razvoj međunarodnih odnosa“.

Kako je već napisano ljudska prava, odnosno prava čovjeka, odnosno prirodna prava kao „nezastariva“ i „,nepotrošiva“ upisana su kao takva u najvažnija pravna

27 Povelja Ujedinjenih naroda, Narodne novine - Međunarodni ugovori, 15/93., 7/94. 
vrela u međunarodnim, regionalnim i nacionalnim okvirima.

\subsection{Europska konvencija za zaštitu ljudskih prava i temeljnih sloboda}

„Već od samog nastanka Vijeća Europe, načelo poštivanja ljudskih prava bilo je jedan od kamena temeljaca te organizacije“. Svaka članica Vijeća Europe mora prihvatiti načela vladavine prava i uživanja ljudskih prava i temeljnih sloboda svih osoba unutar njene jurisdikcije“. Deset država članica Vijeća Europe potpisalo je 4. studenog 1950. u Rimu Europsku konvenciju za zaštitu ljudskih prava i temeljnih sloboda. Konvencija utvrđuje važna načela: osnovu pravde i mira u svijetu; poštovanje slobode i vladavine prava; zajedničku provedbu ljudskih prava; nadzor Europskog suda za ljudska prava (kada pojedinac pokreće postupak o implementaciji prava „na unutarnjem planu“ rada taj Sud „ocjenjuje individualne tužbe“).

Konvencija ,naglašava univerzalnu narav ljudskih prava, jezik država osigurava „svakoj osobi pod svojom jurisdikcijom“. Domaće pravo država mora biti u skladu s Konvencijom. Konvencija utvrđuje: pravo na život (ukida smrtnu kaznu); nitko se ne smije podvrgnuti mučenju ni nečovječnom ili ponižavajućem postupanju ili kažnjavanju; nitko se ne smije držati u ropstvu ili ropstvu sličnom odnosu; nitko se ne smije siliti na prisilan ili obvezatan rad; svatko ima pravo na slobodu i na osobnu sigurnost; pravo na pošteno suđenje; sloboda od retroaktivnog kaznenog zakonodavstva; temelji za ograničenje vršenja prava prema Konvenciji; pravo na poštovanje privatnog i obiteljskog života, doma i dopisivanja, na stupanje u brak i osnivanje obitelji te jednakost supružnika; sloboda mišljenja, savjesti i vjeroispovijesti; sloboda izražavanja i informiranja; sloboda okupljanja i udruživanja; pravo na mirno uživanje vlasništva; pravo na obrazovanje; pravo na slobodne izbore; određena prava državljana i stranaca; zabrana diskriminacije; pravo na djelotvoran domaći pravni lijek i dr. ${ }^{28}$

\subsection{Statut Vijeća Europe ${ }^{29}$}

Statut Vijeća Europe donesen je u Londonu 5. svibnja 1949., u cilju ,jačanja mira utemeljenog na pravdi i međunarodnoj suradnji“, što je „,vitalno za očuvanje ljudskog društva i civilizacije, ali i za osobnu slobodu, političke slobode i za vladavinu prava“‘.

\subsection{Opća Deklaracija UN o ljudskim pravima ${ }^{30}$}

Opća Deklaracija Ujedinjenih naroda o ljudskim pravima iz 1948. po broju i sadržaju prava čovjeka predstavlja „do sada najveću kodifikaciju prirodnih prava u istoriji pravne kulture“". ${ }^{31}$ Pored klasičnih političkih i građanskih prava obuhvaća čitav niz ekonomskih, socijalnih i kulturnih prava za zaštitu digniteta čovjeka kao društvenog bića, koje utvrđuju:

28 Donna Gomien, Europska konvencija o ljudskim pravima (Zadar: Naklada, Pravni fakultet u Rijeci, 2007.). Vidi Narodne novine - Međunarodni ugovori, 6/99., 8/99.

29 Narodne novine - Međunarodni ugovori, br. 8/98., 9/98.

30 Narodne novine - Međunarodni ugovori, br. 12/09.

31 Perović, Besede s Kopaonika, 450. 
1) međunarodni pakt(ovi) iz 1966. ,

2) Europska konvencija o zaštiti ljudskih prava i temeljnih sloboda 1950.,

3) brojne konvencije MOR-a koje ratificiranjem postaju sastavnim dijelom unutrašnjega pravnog poretka (iznad propisa nacionalnog prava). ${ }^{32}$

\section{PRAVNA STEČEVINA EU I NACIONALNO PRAVO}

Pravna stečevina Europske unije skup je prava i obveza koji sve države članice obvezuje i povezuje unutar EU-a. Pravna stečevina EU (franc. acquis communautaire, skraćeno acquis) obuhvaća: sadržaj, načela i političke ciljeve osnivačkih ugovora (tzv. primarno zakonodavstvo), zakonodavstvo usvojeno na temelju osnivačkih ugovora (tzv. sekundarno zakonodavstvo), presude Suda EU, deklaracije i rezolucije koje je EU usvojio, mjere koje se odnose na zajedničku vanjsku i sigurnosnu politiku, mjere koje se odnose na pravosuđe i unutarnje poslove te međunarodne ugovore koje je sklopila Europska zajednica, kao i ugovore zaključene između država članica u području djelovanja EU-a. Pravna stečevina EU-a podijeljena je na 31 poglavlje. Za članstvo u EU-u države su dužne uskladiti nacionalno zakonodavstvo države kandidatkinje s pravnom stečevinom EU-a (u postupku „pristupnog partnerstva i nacionalnog programa za usvajanje pravne stečevine EU-a").

U pravu EU-a, kako je već napisano, posebno mjesto ima zaštita ljudskih prava (temeljnih prava i sloboda). Države članice EU-a, u svojim ustavima i zakonima, posebno uređuju i štite temeljna prava i slobode čovjeka. Posebnu ulogu u EU-u ima Sud EU na temelju primarnih i drugih akata EU-a, ali i na temelju poticaja nacionalnih sudova i drugih subjekata koji su pred njim tražili zaštitu temeljnih prava i sloboda.

Sud EU priznaje „direktnu primjenu - djelovanje i supremaciju europskog prava u odnosu na nacionalno pravo". Nijedna odredba nacionalnog propisa ne smije „dovesti u pitanje osnovna ljudska prava koja su sadržana u općim principima prava EU“ i koje štiti Europski sud i mora se „osigurati u pravnom sustavu EU-a“.

Europski sud može poništiti propis EU-a „koji je u suprotnosti s osnovnim ljudskim pravima“, odnosno „sud ne može podržati mjere koje su u raskoraku s osnovnim pravima koje priznaju i štite ustavi država članica i međunarodni sporazumi o zaštiti ljudskih prava“".

Tako principijelna stajališta ima i Europski sud za ljudska prava u Strasbourgu kada je u pitanju Europska konvencija o ljudskim pravima i slobodama (EKLJPS).

U primarnim aktima EU-a utvrđuje se „koji odnosi i pravo reguliranja je preneseno na nadnacionalni nivo. Pravo EU-a važi za sve fizičke i pravne osobe na prostoru EU-a, odnosno ,prostoru država članica EU koji je u njihovoj jurisdikciji“.

Pravo EU-a je „novi pravni poredak i čini neposredno ostvariva prava i obveze i kao takvo je nadređeno (više) u odnosu na nacionalno pravo". ${ }^{33}$ To se izvodi iz

32 „Prirodna prava čovjeka danas ne mogu biti ostvarena u 1/5 stanovništva, jer se taj dio svijeta (preko milijardu ljudi) nalazi u stanju ekstremnog siromaštva." Stotine milijuna ljudi umire od gladi i nehigijenskih uvjeta... pa se o ljudskim pravima može govoriti samo u fikcijama Perović, Besede s Kopaonika, 456.

33 O tome su razvijene različite teorije: o supremaciji prava EU-a; o neposrednom djelovanju; o njihovoj posebnosti i autonomnosti (posebno u zaštiti ljudskih prava); o odgovornosti država za (ne)primjenu prava EU-a i druge. 
osnivačkih ugovora i drugih vrela koja spadaju u primarno pravo EU-a (što po nekim autorima čini ,ustav“ zajednice EU-a).

To se, posebno odnosi na norme prava EU-a kojima se uređuju i štite temeljna ljudska prava i slobode. Za ta prava i slobode, pa i za pravo na radu (odnosno ona koja su kao temeljna uređena vrelima prava MOR-a), ne može biti drukčije: ona su opća, nadnacionalna i trajna.

\section{ZAKLJUČAK}

Prošlo je stotinu godina od osnivanja i rada MOR-a specijalizirane međunarodne organizacije Ujedinjenih naroda (UN) u stvaranju, nadzoru i zaštiti normi Međunarodnog radnog prava, s originalnom organizacijom, financiranjem i sadržajem rada. MOR je jedina tripartitna međunarodna organizacija (predstavnika vlada, poslodavaca i radničkih sindikata država članica).

Ustav MOR-a, konvencije i preporuke koje donosi Opća skupština MOR-a utvrđuju temeljna prava i slobode čovjeka (radnika) na radu, za koja nema „zamjene“. Nema kolizije o tim pitanjima i odnosima među normama prava MOR-a i pravnoj stečevini EU-a (acquis comunaitaire) i ne trebaje, ,tražiti“. Ljudska prava su jedinstvena i trajna. To je određeno u aktu o osnivanju i preambuli Ustava MOR-a, određeni su ciljevi i karakteristike te, po svemu, jedinstvene međunarodne organizacije (stalnost i neprekidnost, univerzalnost, tripartitnost). Ustavom je „postavljena“ originalna i funkcionalna organizacija MOR-a (Opća skupština, Upravno vijeće i Međunarodni ured rada, na čijem je čelu glavni direktor s preko 3.000 radnika u službama).

Najvažnija je normativna aktivnost MOR-a donošenje konvencija i preporuka, kojima je stvorila (i stvara) norme, standarde i osnove međunarodnog radnog prava. Konvencije i preporuke karakteriziraju specifične (objektivne) nomotehničke oznake. Njima se „postavljaju“ minimalni standardi ljudskih prava u radnim odnosima. Predviđena je primjena načela in favorem laboratores. Nema niti jednog pitanja važnog za prava čovjeka (radnika) na radu u kolektivnim i individualnim radnim odnosima da nisu, barem u osnovi uređena navedenim normama (propisima).

Standardi prava čovjeka na radu utvrđeni u aktima MOR-a, a i u drugim općim i regionalnim vrelima ljudskih prava i sloboda, potvrđuju snagu i opravdanost osnivanja i postojanja MOR-a. Pozitivno pravo država još nije dostiglo zahtjeve tih vrela. Ti zahtjevi služe pravdi i „pravednom pravu“. Svojim radom i dokumentima MOR-a postigla je moralni autoritet, profesionalnu odgovornost $i$ administrativnu učinkovitost, a socijalnu pravdu stavila u središte rasprave, zakonska rješenja treba tražiti (i naći) u vrelima ljudskih prava i sloboda.

Tripartitnost MOR-a danas se ostvaruje sa 187 država članica. To je omogućilo da se donese 189 konvencija i 205 preporuka, što čini nezamjenjivi fond i svojevrsni kodeks međunarodnoga radnog prava. Ljudska prava i dalje ostaju kao pokretačka snaga uređivanja odnosa života i rada „različitim oblicima organiziranja“ i da „,izvedu svijet iz krize u kojoj se nalazi“. To će omogućiti visoki „standard tolerancije pod okriljem UN-a i MOR-a, i drugih univerzalnih i regionalnih subjekata, koji stvaraju kompoziciju ljudskih prava i sloboda. Ona se odnose na svakoga čovjeka u svijetu, koji može biti jak samo kroz kolektivnu podršku u ostvarivanju prava čovjeka. 
Razvojni procesi nisu i ne mogu biti zaustavljeni. To važi i za ljudska prava i slobode. Za to su odgovorne sve države članice UN-a i MOR-a, pred licem cijeloga svijeta. Iz prava na život i slobodu proizlaze i druga ljudska prava, pa i ona iz rada. Ona su nezastariva i „nepotrošiva“, opća i nadnacionalna.

\section{LITERATURA}

1. Blanpain, Roger. European Labour Law. London/New York: Walters Kluwer, 2003.

2. Bodiroga-Vukobrat, Nada i Sanja Barić. Povelja temeljnih prava EU. Zagreb: Organizator, Zagreb, 2002.

3. Buklijaš, Boris. Kolektivno radno pravo. Split: Pravni fakultet, Split, 2006.

4. Dedić, Sead i Jasminka Gradašćević Sijerčić. Temelji međunarodnog radnog prava. Sarajevo: Pravni Centar FOD BIH, 2000.

5. Europska konvencija o zaštiti ljudskih prava i temeljnih sloboda. Narodne novine Međunarodni ugovori. 6/99, 8/99.

6. Europska socijalna povelja, Narodne novine - Međunarodni ugovori. br. 15/02, 8/03.

7. Gomien, Donna. Europska konvencija o ljudskim pravima. Zadar: Naklada, Pravni fakultet u Rijeci, 2007.

8. Herman, Vilim i Milorad Ćupurdija. Osnove radnog prava. Osijek: Pravni fakultet, 2011.

9. Kenović, Mehmed i Sead Dedić. Osnovi radnog prava. 2. izd. Sarajevo: Pravni fakultet, Studentska štamparija Univerziteta, 1999.

10. Lubarda, Branko. Europsko radno pravo. Podgorica: CID 2004.

11. Opća deklaracija Ujedinjenih naroda o ljudskim pravima. Narodne novine-Međunarodni ugovori. br. $12 \%$.

12. Perović, Slobodan. Besede s Kopaonika. Beograd: Kopaonička škola prirodnog prava, 2011. i 2012.

13. Povelja Ujedinjenih naroda. Narodne novine - Međunarodni ugovori. 15/93, 7/94.

14. Statut Vijeća Europe. Narodne novine - Međunarodni ugovori. br. 8/98, 9/98.

15. Tintić, Nikola. Radno i socijalno pravo. (Knj. 1.: Radni odnosi). Zagreb: Narodne novine, Zagreb, 1969.

16. Učur, Marinko. Radnopravni status pomoraca. Rijeka: Pravni fakultet, Rijeka, 2003.

17. Učur, Marinko. Vrela radnog prava. Rijeka: Pravni fakultet, Rijeka, 1996.

18. Učur, Marinko i Sandra Laleta. Konvencija međunarodne organizacije rada, $s$ komentarima. TIM press, Pravni fakultet, Rijeka, 2007.

19. Ustav Republike Hrvatske, Narodne novine. br 56/90. 


\title{
Marinko Učur*
}

\author{
Summary
}

\section{RICHNESS AND DURABILITY OF HUMAN RIGHTS IN LEGAL SOURCES (DOCUMENTS) OF THE INTERNATIONAL LABOUR ORGANISATION (100 YEARS OF ILO, 1919-2019)}

The founding and launching of the International Labour Organization (ILO) in 1919 continued the centuries-long journey and development of natural rights ("human rights") and their legal formation of capricious and heterogeneous relations (of all content) in the world. The ILO Constitution has been in force for a hundred years, and under which the General (General) Assembly UN has passed Conventions, Recommendations and other documents on working conditions (in the broadest sense), which by ratification and acceptance have become part of the legal system of States and by legal force above national law. The sources of UN law and other legal and legitimate international and regional organizations, the principles and norms of law created (and still creating) by the ILO form the body of international labor (and social) law.

The subject of this paper is a review of the hundred years "treasure" created under the auspices of the ILO on human rights and freedoms, primarily at work (human rights and freedoms at work), and the attitude that no legal norm of positive law should conflict with the principles and rules on human rights and freedoms.

Keywords: International Labour Organization; human rights and freedoms; sources of International Labour Law; working conditions and human rights at work.

Zusammenfassung

\section{REICHTUM UND BESTÄNDIGKEIT VON MENSCHENRECHTEN IN RECHTSQUELLEN (DOKUMENTEN) DES INTERNATIONALEN ARBEITSORGANISATION (100 JAHRE IAO, 1919-2019)}

Mit der Gründung des Internationalen Arbeitsorganisation in 1919 hat man den jahrhundertelangen Weg und die jahrhundertelange Entwicklung von Naturrechten

* Marinko Učur, Ph.D., Retired Full Professor, University of Rijeka, Faculty of Law; marinko. ucur051@gmail.com. 
(Menschenrechten) und ihre rechtliche Gestaltung in unbeständigen und heterogenen Beziehungen (zwischen allen Inhalten) in der Welt fortgesetzt. Die IAO-Verfassung, aufgrund deren die UN-Generalversammlung Konventionen und Empfehlungen und andere Dokumente über Arbeitsbedingungen (im weitesten Sinne des Wortes), die durch Ratifizierung Teil der Rechtssysteme von Staaten und der Rechtskraft nach dem Nationalgesetz übergeordnet wurden, erlies, ist schon seit hundert Jahren in Kraft. Die Rechtsquellen der UN und anderer legaler und legitimer internationaler und regionaler Organisationen sowie auch die vom IAO geschaffenen Grundsätze und Normen des Rechts stellen das Kern des internationalen Arbeits- und Sozialrechts dar.

In diesem Beitrag berücksichtigt man das jahrhundertelange Reichtum, das unter der Schirmherrschaft des IAO über Menschenrechte und Freiheiten, insbesondere bezüglich der Arbeit (Rechte und Freiheiten am Arbeitsplatz), geschaffen wurde. Ebenfalls erörtert man die Ansicht, dass keine Norm des positiven Rechts mit Grundsätzen und Regeln über Menschenrechte und Freiheiten kollidieren darf.

Schlüsselwörter: Internationale Arbeitsorganisation; Menschenrechte und Freiheiten; Quellen des internationalen Arbeitsrechts; Arbeitsbedingungen und Menschenrechte am Arbeitsplatz.

Riassunto

\section{LA RICCHEZZA E LA CONTINUITÀ DEI DIRITTI UMANI NELLE FONTI GIURIDICHE (DOCUMENTI) DELL'ORGANIZZAZIONE INTERNAZIONALE DEL LAVORO (100 ANNI DELL'OIL, 1919.-2019.)}

Con la costituzione e gli inizi delle attività dell'Organizzazione internazionale del lavoro nel 1919 s'è perpetuato il cammino secolare e lo sviluppo dei diritti naturali (dei diritti umani "diritto dell'uomo") ed il loro modellamento giuridico nei rapporti volubili ed eterogeni (in tutti i contenuti) esistenti al mondo. Già da un secolo è in vigore la Costituzione dell'OIL in forza della quale l'Assemblea Generale dell'ONU ha emanato convenzioni e raccomandazioni, come anche altri documenti riguardanti le condizioni di lavoro (nel senso più lato del termine), divenute poi, mediante la ratifica e l'accettazione, parte dell'ordinamento giuridico degli stati, sistemandosi quanto alla loro forza legale al di sopra della legge nazionale. Le fonti giuridiche dell'ONU e delle altre organizzazioni internazionali e regionali legali e legittime, come anche i principi e le norme che ha creato (e crea) l'OIL costituiscono il corpus del diritto internazionale del lavoro e dei diritti sociali.

L'oggetto di questo lavoro è una rassegna della ricchezza centenaria creata sotto l'operato dell'OIL riguardante i diritti umani e le libertà, in primo luogo nell'ambiente di lavoro (diritti e libertà dell'uomo sul lavoro) nella convinzione che nessuna norma del diritto positivo possa collidere con i principi e le regole sui diritti dell'uomo e le libertà. 
Parole chiave: Organizzazione internazionale del lavoro; diritti umani e libertà; fonti del diritto internazionale del lavoro; condizioni di lavoro e diritti dell'uomo al lavoro. 